\title{
Fusarium mangiferae as New Cell Factories for Producing Silver Nanoparticles
}

\author{
Haider M. Hamzah ${ }^{1 *}$, Reyam F. Salah ${ }^{2}$, and Mohammed N. Maroof ${ }^{3}$ \\ ${ }^{1}$ Department of Biology, College of Science, University of Sulaimani, Slemani, Kurdistan Region, Iraq \\ ${ }^{2}$ Department of Biology, College of Science, Tikrit University, Iraq \\ ${ }^{3}$ Department of Biology, College of Education for Pure Sciences, Tikrit University, Iraq
}

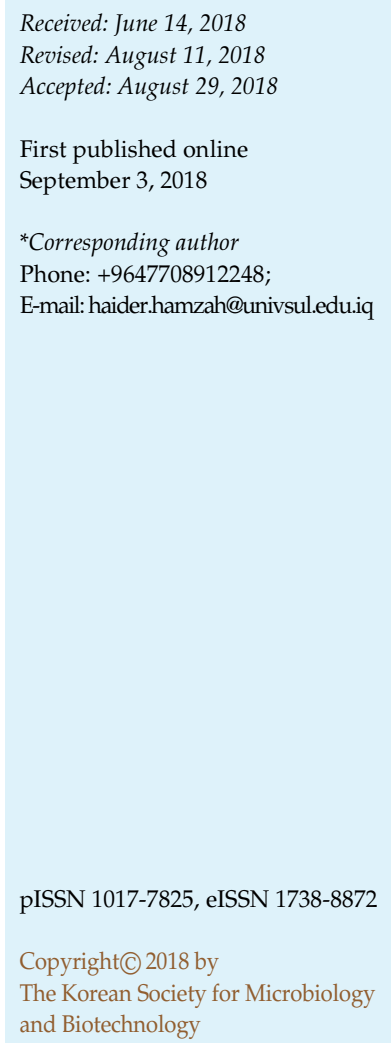

Finding a safe and broad-spectrum medication is a goal of scientists, pharmacists, and physicians, but developing and fabricating the right medicine can be challenging. The current study describes the formation of silver nanoparticles (AgNPs) by Fusarium mangiferae. It involves the antibiofilm activity of the nanoparticles against Staphylococcus aureus. It also involves cytotoxic effect against mammalian cell lines. Well-dispersed nanoparticles are formed by F. mangiferae. The sizes of the nanoparticles were found to range from 25 to $52 \mathrm{~nm}$, and UV-Vis scan showed absorption around 416-420 nm. SEM, TEM, and AFM results displayed spherical and oval shapes. Furthermore, the FTIR histogram detected amide I and amide II compounds responsible for the stability of AgNPs in an aqueous solution. AgNPs were observed to decrease the formation of biofilm at $75 \%(\mathrm{v} / \mathrm{v})$. DNA reducing, smearing, and perhaps fragmentation were noticed after treating the bacterial cells with $50 \%(\mathrm{v} / \mathrm{v})$. Additionally, cell lysis was detected releasing proteins in the supernatant. It was also observed that the AgNPs have the ability to cause 59\% cervical cancer cell line (HeLa) deaths at $25 \%(\mathrm{v} / \mathrm{v})$, however, they showed about $31 \%$ toxicity against rat embryo fibroblast transformed cell lines (REF). The results of this study prove the efficiency of AgNPs as an antibiofilm against $S$. aureus, suggesting that AgNPs could be an alternative to antibiotics. It must also be emphasized that AgNPs displayed cytotoxic behavior against mammalian cell lines. Further studies are needed for assessing risk in relation to the possible benefit of prescribing AgNPs.

Keywords: Fusarium mangiferae, silver nanoparticles, Staphylococcus aureus, antibiofilm, mammalian cell lines

\section{Introduction}

Advances in nanotechnology have allowed the synthesis of nanoparticles which are considered a feasible alternative to antibiotics and seem to be the solution to the problem of microbial multidrug resistance. Increasingly, multidrugresistant (MDR) microbes are a growing dilemma and the cause of a public health crisis, particularly in the treatment of infectious diseases [1]. On the other hand, several pathogens can form biofilms composed of extracellular polymeric substances (EPS) that are responsible not only for a communication phenomenon but display resistance to antibiotics and host defense systems [2, 3, 4]. Besides that, biofilm attaches to many medical devices and foreign body materials (e.g., catheters, contact lenses, and artificial heart valves) causing chronic and hard-to-treat infections, particularly in immunocompromised patients $[5,6]$. Thus, experts are facing a lot of challenges to find robust drugs or antimicrobial agents that are effective against biofilmforming microbes such as Staphylococcus aureus.

S. aureus is an opportunistic pathogen; some strains are resistant to a wide range of antibiotics and and are capable of evading the host immune system [7]. There are no complete therapies for treating and preventing chronic 
biofilm-mediated infections; however, several available alternative choices such as silver nanoparticles (AgNPs) are in use and are being tested $[8,9]$. Several publications have hypothesized that AgNPs are involved in disruption of the membrane with the generation of reactive oxygen species (ROS) and ultimately lead to the death of pathogens $[6,10$, 11]. One possible mechanism is that AgNPs have the ability to adhere to the bacterial cell wall and produce cracks and pits, through which the internal cell contents are released [12]. Although $\mathrm{AgNO}_{3}$ has potential toxicity to humans, its nanoparticles are medically promising for being highly effective as antimicrobial agents [1] and the least toxic [13]. However, the toxicity of AgNPs needs to be studied extensively to determine whether the benefits of taking nanoparticles outweigh potential risks. At the same time, silver nanoparticles have potential therapeutic properties in treating a variety of diseases including cancers. For instance, AgNPs induced cytotoxic effects in Dalton's lymphoma ascites (DLA) tumor system in vitro, inhibiting tumor progression and thereby effectively controlling disease development without toxicity to normal cells [14]. Furthermore, Arora et al. [15] have suggested a promising role for AgNPs as novel chemo-preventive agents against UVB-irradiation-induced skin carcinogenesis. Other studies have illustrated the in vitro inhibitory effects of AgNPs on human lung epithelial cells and rat cells $[16,17]$. Generally, silver ions disrupt the mitochondrial permeability transition pore in mitochondrial membranes, increasing mitochondrial swelling, and eventually resulting in cellular apoptosis or necrosis as a result of ROS production [18, 19].

In recent years, there has been an increasing interest in mycosynthesis of AgNPs due to its efficacy [1, 20,21]. In this context, filamentous fungi have become important for AgNP makers, where producing unique nanoparticles plays a key supporting role in the growing industry of synthetic biology. The filamentous fungi Fusarium species that have previously been used in reducing aqueous silver ions extracellularly to generate silver NPs, are F. oxysporum [22], F. acuminatum [23], F. semitectum [24], F. solani [25], F.culmorum [26], F. graminearum, F. scirpi, F. tricinctum, F. proliferatum, F. equiseti, and F. moniliforme [27]. To the best of our knowledge, there is no report of $F$. mangiferae as being a new AgNP factory. F. mangiferae has been associated with mango malformation [28]. However, mango leaves inoculated with F. mangiferae isolate did not produce any disease symptoms and remained healthy [29]. In this study, we synthesized AgNPs using the filamentous fungus F. mangiferae and investigated its antibiofilm activity against biofilm forming S. aureus. Additionally, we conducted experiments to detect the cytotoxicity behavior of AgNPs against two mammalian cell lines.

\section{Materials and Methods}

\section{Synthesis of AgNPs}

F. mangiferae (FQ) was used for the synthesis of AgNPs. Colonies of $F$. mangiferae were grown on Potato Dextrose Agar (PDA) plates for 6 days at $28^{\circ} \mathrm{C}$ and were used to inoculate $250 \mathrm{ml}$ MYPG medium (consisting of $3 \mathrm{~g}$ malt extract, $3 \mathrm{~g}$ yeast extract, $2 \mathrm{~g}$ peptone, and $10 \mathrm{~g}$ glucose per liter) in Erlenmeyer flasks. The flasks were incubated at $28^{\circ} \mathrm{C}$ for 7 days with shaking at $150 \mathrm{rpm}$ using shaking incubator (GFL, Germany). Mycelial pads were harvested aseptically and washed three times with distilled water. The biomass of fungi was weighed and then used for the synthesis of nanoparticles according to Ahmed et al. [1].

\section{Characterization of AgNPs}

The synthesized NPs were characterized based on specific surface plasmon resonance peak, shape, size and interaction between protein and NPs. To confirm the synthesis of AgNPs, $3 \mathrm{ml}$ of sample was used for UV-Vis scan at wavelengths ranging from 300-600 nm using a Genesys 6 spectrophotometer (Thermo Electron Corporation, USA). The nanoparticles were subjected to microscopic characterization, i.e. scanning electron microscope (SEM), transmission electron microscope (TEM), and atomic force microscope (AFM) [1]. To identify the presence of possible biomolecules, Fourier transmission infrared spectroscopy (FTIR, WQF-520, Biotech, England) was employed [1].

\section{Antigrowth and Antibiofilm Activities of AgNPs}

An isolate of $S$. aureus obtained from Sulaimani Teaching Hospital in Kurdistan Region, Iraq, was multidrug resistant. The activity of AgNPs was tested against $S$. aureus as inhibitors using a microtiter plate. Fresh overnight culture of pathogenic bacterial isolate was adjusted to be $10^{8}$ cells per ml. A bacterial culture of $120 \mu \mathrm{l}$ was placed in a 96-well microtiter plate and then $80 \mu \mathrm{l}$ of an appropriate dilution of AgNPs (25\%, 50\%, 75\%, and 100\% (v/v)) was added. Nutrient broth $(200 \mu \mathrm{l})$ was used as a negative control and $120 \mu \mathrm{l}$ of bacterial culture mixed with $80 \mu \mathrm{l}$ of fungal extract was also employed as a negative control. The microtiter plates were incubated at $37^{\circ} \mathrm{C}$ for $18 \mathrm{~h}$ [1]. The optical density (OD) at $600 \mathrm{~nm}$ was measured using Microplate Spectrophotometer (Biotech $\mu$ Quant, USA). Growth percentage was calculated based on the average and standard deviation of triplicate results. Besides the growth inhibition assay, spot inoculation was also evaluated. Five $\mu \mathrm{l}$ was taken from each well and spotted on nutrient agar and Congo red agar (CRA) plates. Then all plates were incubated at $37^{\circ} \mathrm{C}$ for $18 \mathrm{~h}$. CRA was used to detect, qualitatively, biofilm production. CRA was prepared by mixing $3.7 \%(\mathrm{w} / \mathrm{v})$ Brain Heart Infusion broth (Difco) with $0.08 \%(\mathrm{w} / \mathrm{v})$ Congo red (Sigma-Aldrich, Germany) supplemented with 5\% (w/v) sucrose and $1.5 \%(\mathrm{w} / \mathrm{v})$ agar [30]. 
Biofilm formation was inspected according to Mathur et al. [31] with a few modifications. Nutrient broth (NB) was inoculated with bacterial cells and incubated under shaking for $24 \mathrm{~h}$ at $37^{\circ} \mathrm{C}$. Cells were adjusted to be $10^{8} \mathrm{cell} / \mathrm{ml}$, then a Tissue Culture Plate (TCP) approach was used. About $200 \mu \mathrm{l}$ cultures were placed in a 96-well microtiter plate. The plate was then incubated for $24 \mathrm{~h}$ at $37^{\circ} \mathrm{C}$ under a gentle shaking in microplate incubator-shaker PST60 HL Plus (BOECO, Germany). Biofilm was measured by discarding the medium and rinsing the wells three times with $200 \mu \mathrm{l}$ phosphate buffer saline (PBS, pH 7.2). After drying, the attached cells were stained with crystal violet $(0.1 \%)$ for $30 \mathrm{~min}$. After staining, the liquid was discarded and the wells were rinsed three times with distilled water. The plate was then allowed to dry at room temperature, after which $200 \mu$ lethanol (95\%) was added to the wells to solubilize the stain. The absorbance at $595 \mathrm{~nm}$ was measured via Microplate Spectrophotometer (Biotech $\mu$ Quant, USA). OD readings were used as an indicator of the bacterial biofilm formation, and then converted to percent of inhibition (\%). To confirm that the AgNPs had anti-biofilm activity, different concentrations ( $0 \%, 25 \%, 50 \%, 75 \%$, and $100 \%(\mathrm{v} / \mathrm{v}))$ of AgNPs were used. Biofilm formation was determined as mentioned above. This experiment was performed three times and then averages and standard deviations (STDEV) were calculated using Microsoft Excel.

\section{Outer Membrane Disturbing Test}

In order to elucidate the antibacterial mode of AgNPs on cell membranes, scanning electron microscopy (SEM) technique was used. One hundred microliters of broth culture of S.aureus incubated with AgNPs $(50 \%(\mathrm{v} / \mathrm{v}))$ for $24 \mathrm{~h}$ were centrifuged at 3,000 $\times g$ for 10 min using Centrifuge $5702 \mathrm{R}$ (Eppendorf, Germany). The cells were then washed with PBS and fixed in 2.5\% glutaraldehyde for $24 \mathrm{~h}$ at room temperature. Thereafter, cells were dehydrated through a graded ethanol series $(70 \%, 85 \%, 90 \%$, and $100 \%)$. Then, the sample from each group was sputter coated with carbon. The same procedure was followed without AgNPs and served as a negative control [32].

\section{Protein Leakage Assay}

The effect of silver nanoparticles on membrane damage was further studied by quantifying the leaked cytoplasmic proteins. Protein leakage from bacterial cells was determined using Biuret method (CHRONOLAB SYSTEMS, Spain). Briefly, bacterial cell suspension with an absorbance of 0.2 at $600 \mathrm{~nm}\left(\sim 10^{8}\right.$ cells per ml) was prepared in NB and treated with AgNPs at $0 \%, 25 \%, 50 \%$, $75 \%$, and $100 \%(\mathrm{v} / \mathrm{v})$ for about $12 \mathrm{~h}$. Samples were centrifuged at $3,000 \times g$ for 20 min using Centrifuge $5702 \mathrm{R}$ (Eppendorf, Germany), and supernatants were subjected for protein quantification.

\section{DNA Profile Analysis}

To assess DNA reduction, genomic DNA from S. aureus (before and after treatment with $50 \%$ AgNPs) was extracted using the protocol described by Thottappilly et al. [33] and Onasanya et al.
[34] with some modifications. Briefly, about $0.3 \mathrm{~g}$ of washed bacterial cells were suspended in $200 \mu \mathrm{l}$ of $2 \times \mathrm{CTAB}$ buffer (50 mM Tris, $\mathrm{pH} \quad 8.0 ; 0.7 \mathrm{mM} \mathrm{NaCl} ; 10 \mathrm{mM}$ EDTA; $2 \%$ hexadecyltrimethylammonium bromide; $0.1 \%$ 2-mercaptoethanol), followed by the addition of $100 \mu \mathrm{l}$ of $20 \%$ sodium dodecyl sulfate and incubated at $65^{\circ} \mathrm{C}$ for $20 \mathrm{~min}$. DNA was purified by three extractions with phenol:chloroform:isoamyl alcohol (24:25:1) and then cold $99 \%$ ethanol was added to the aqueous layer and kept at $-20^{\circ} \mathrm{C}$ for $20 \mathrm{~min}$. After this stage, the solution was centrifuged at $10,000 \times g$ for $20 \mathrm{~min}$ using Mikro 200R (Hettich, UK). After washing with $70 \%$ ethanol, the DNA was dried and resuspended in $50 \mu \mathrm{l}$ of sterile distilled water. The DNA profile was checked by electrophoresis on a $1 \%$ agarose gel in 1 xTAE ( $45 \mathrm{mM}$ Tris-acetate, 1 mM EDTA, pH 8.0).

\section{Cytotoxicity Assay}

Rat embryo fibroblast transformed cell lines (REF cells) and cervical cancer cell line (HeLa cells) were used in this study. The cell lines were obtained from the Iraqi Center for Genetics and Cancer Research-Baghdad, Iraq, and maintained in RPMI 1640 (Sigma-Aldrich, Germany) supplemented with 5\% calf bovine serum (ICCMGR), 100 units $/ \mathrm{ml}$ penicillin, and $100 \mu \mathrm{g} / \mathrm{ml}$ streptomycin. Cell proliferation was evaluated according to Betancur-Galvis et al. [35] with modifications. In brief, mammalian cell lines (120 $\mu \mathrm{l}$ of $10^{8} \mathrm{cell} / \mathrm{ml}$ ) was seeded in a 96-well tissue culture plate. Then, $80 \mu \mathrm{l}$ of different concentrations of AgNPs ( $0 \%, 25 \%, 50 \%$, 75\%, and $100 \%(\mathrm{v} / \mathrm{v}))$ were added. Cells were cultured overnight at $37^{\circ} \mathrm{C}$ and were then washed with PBS, followed by $50 \mu$ l of crystal violet solution (crystal violet solution was prepared according to Mather and Roberts (1998) [36]. Afterwards, the plate was measured at $492 \mathrm{~nm}$ using a microtiter plate reader (Organon Teknika Reader 230S, Austria). The data were analyzed using Microsoft Excel and depicted as a graphic representation. The assay was performed in triplicate and cytotoxicity was expressed as the percentage of viable cells at different concentrations of samples. The percentage of cytotoxicity (Inhibition \%) was calculated as: $(\mathrm{A}-\mathrm{B}) / \mathrm{A} \times 100$, where $\mathrm{A}$ is the mean optical density of untreated wells and $B$ is the optical density of treated wells. $\mathrm{IC}_{50}$, the value that kills $50 \%$ of cultured cells, was calculated from the dose-response curve.

\section{Results}

\section{Characterization of AgNPs}

F. mangiferae (FQ) was able to convert $\mathrm{AgNO}_{3}$ into $\mathrm{AgNPs}$ after $190 \mathrm{~h}$ of incubation as noticed visually by color change from purple to dark brown, whereas the control vessels developed no change in their original color (Fig. 1; inset). The wavelength scan of UV-Vis spectra revealed a broad peak between 416 to $419 \mathrm{~nm}$ indicating the surface plasmon resonance (SPR) nature of the AgNPs that is present in the dark brown supernatant (Fig. 1). 


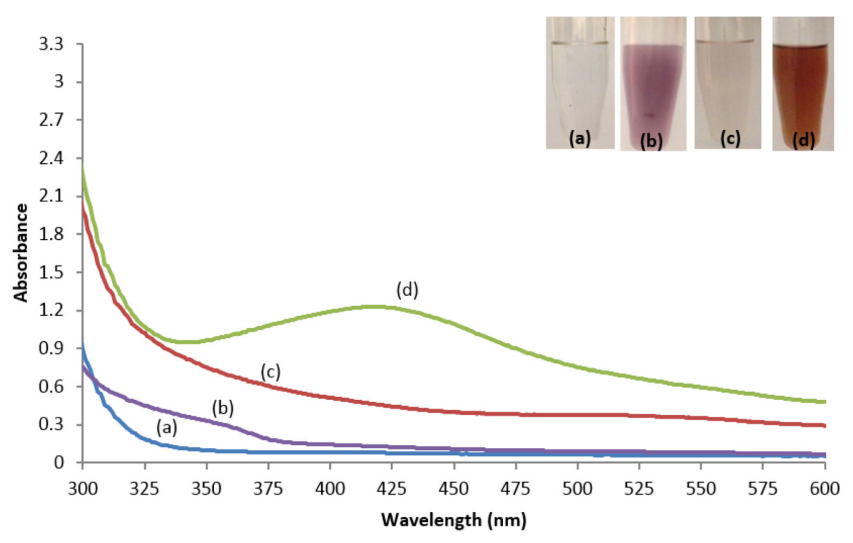

Fig. 1. UV-Visible absorption spectrum of AgNPs.

(a) $\mathrm{AgNO}_{3}$ solution $(1 \mathrm{mM})$ control. (b) Biomass of FQ test sample before incubation. (c) Supernatant of FQ; control. (d) Biomass of FQ; test sample. Inset: Color change of filtrate from purple (b) to dark brown (treated) after synthesis of AgNPs (d).

SEM was used to determine the presence and size of AgNPs. After drying, the thin layer of AgNPs was analyzed. The scanning electron micrograph shows a presence of high-density AgNPs with mainly spherical shape (Fig. 2A; white arrows). The data obtained from TEM micrographs show that the synthesized AgNPs have a spherical shape and the size ranged from 25-52 nm uniformly distributed and also showed a few aggregations (Fig. 2B; white arrows). A two-dimensional horizontal cross section of the AgNPs by AFM indicated that the surface topography of the synthesized silver nanoparticles was almost spherical in shape (Fig. 2C). A histogram analysis revealed that the mean particle size was approximately $48.5 \mathrm{~nm}$.

The absorption peaks of AgNPs (Fig. 3) are located in the region of $523-3,388 \mathrm{~cm}^{-1}$ in FT-IR. The band at $3,388 \mathrm{~cm}^{-1}$ is assigned to the stretching vibrations of $-\mathrm{NH}$ identified as the amide I band, whereas the bands at $1,626 \mathrm{~cm}^{-1}$ represent $-\mathrm{NH}_{2}$. At $1,523 \mathrm{~cm}^{-1}$ shows the stretching vibration of $-\mathrm{C}=\mathrm{O}$ (carbonyl). On the other hand, the bands at $1,404 \mathrm{~cm}^{-1}$ and $2,939 \mathrm{~cm}^{-1}$ represent $\mathrm{C}-\mathrm{H}$ and $\mathrm{C}-\mathrm{H}_{2}$, respectively.

\section{Antigrowth and Antibiofilm Activities of AgNPs}

The action of AgNPs on multidrug-resistant clinical isolate $S$. aureus was carried out by comparing growth and biofilm rate under control and test conditions (Fig. 4). AgNPs show antimicrobial activity in which $75 \%(\mathrm{v} / \mathrm{v})$ of AgNPs inhibited 59\% growth of S. aureus. Additionally, AgNPs reduced the biofilm formation in $S$. aureus significantly. Notably, changes in colony colors on CRA in the presence of nanoparticles indicate that AgNPs have significant roles as antibiofilm activity against $S$. aureus (Fig. 4 ; inset). The biofilm formation is diminished to about $50 \%$ when $50 \%$ (v/v) of AgNPs was used (Fig. 4).
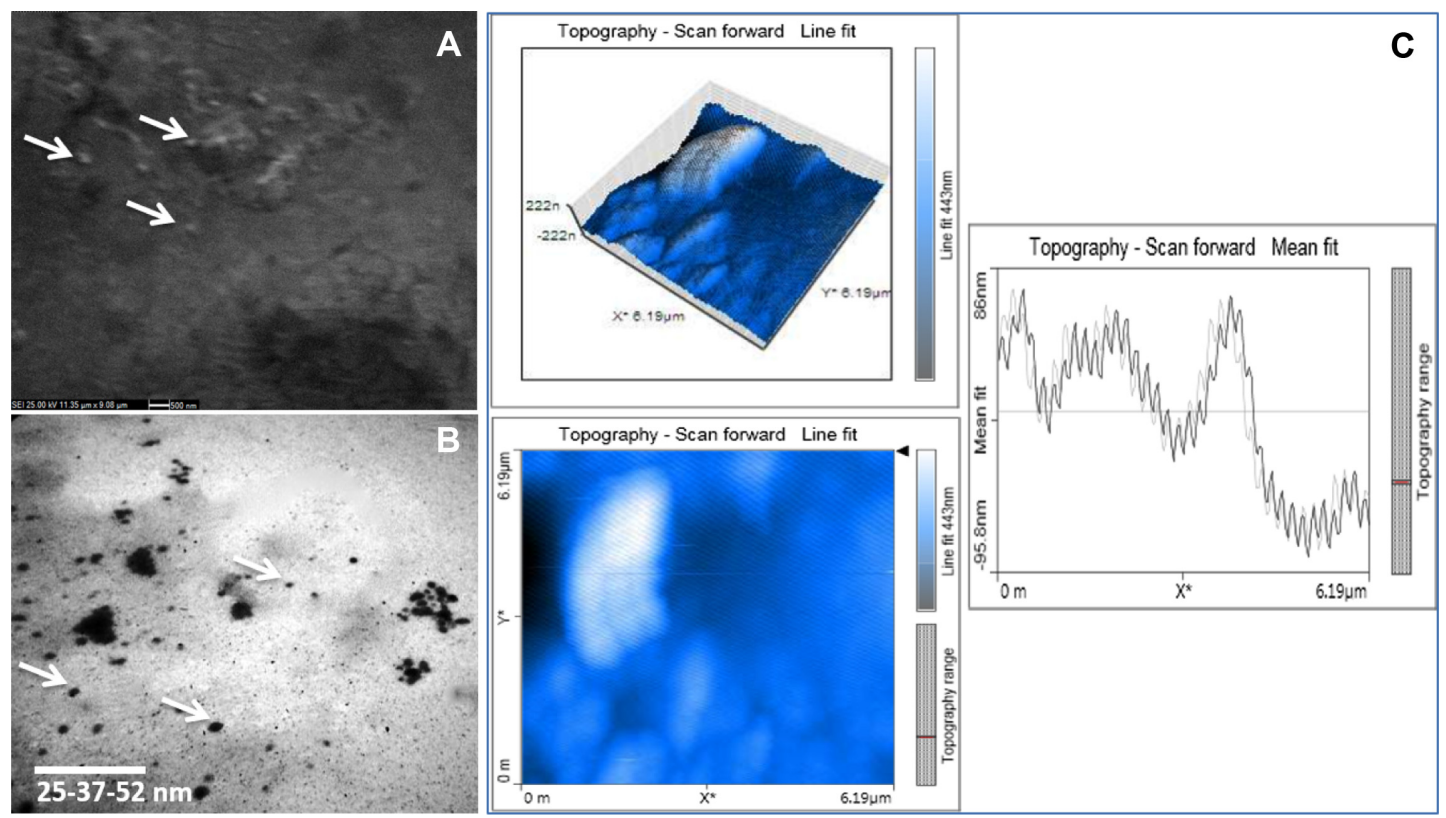

Fig. 2. Micrograph of AgNPs synthesized by FQ.

(A) SEM image. (B) TEM image. (C) AFM images (Left upper picture depicts the 3D image of the AgNPs; whereas left lower picture represents the 2D image of the AgNPs horizontal cross section. Right image indicates the histogram analysis showing the average particle size $48.5 \mathrm{~nm}$ ). 


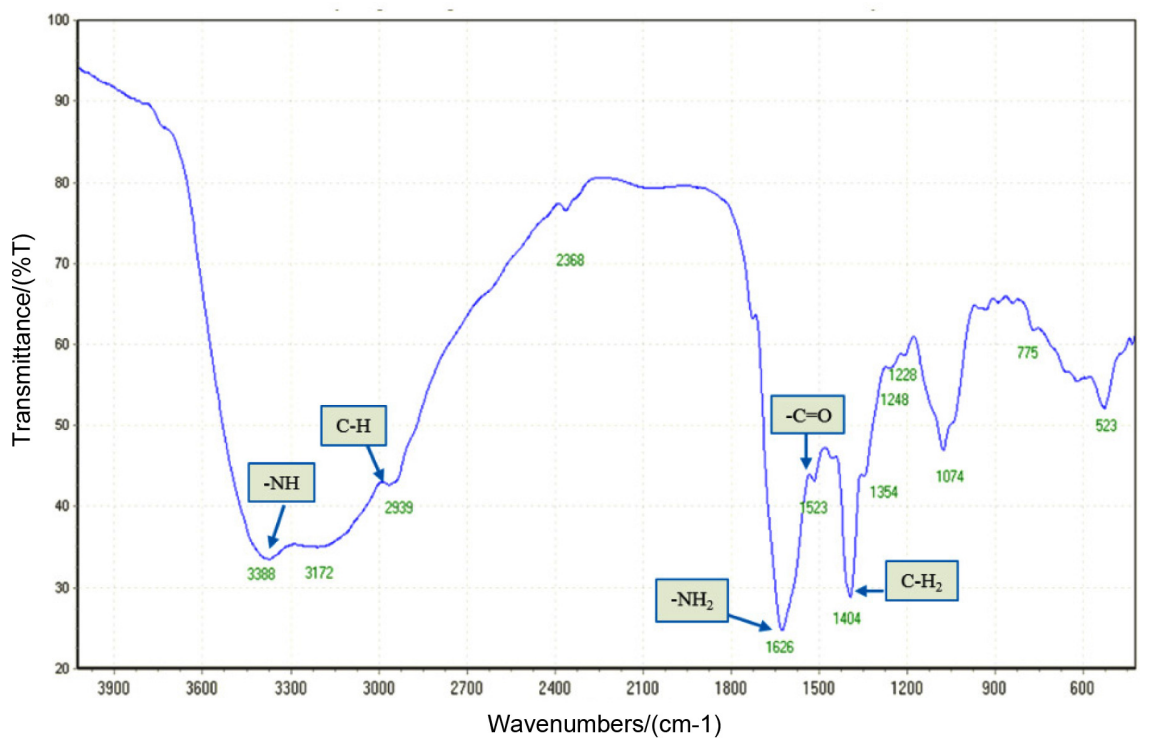

Fig. 3. FT-IR spectrum of silver nanoparticles synthesized by FQ. Green boxes depict- $\mathrm{C}=\mathrm{O},-\mathrm{NH},-\mathrm{NH}_{2}, \mathrm{C}-\mathrm{H}$ and $\mathrm{C}-\mathrm{H}_{2}$ bands.

\section{Outer Membrane Disruption and DNA Profile of S. aureus by the Action of AgNPs}

In the present study, the preliminary mechanistic actions of AgNPs on S. aureus have been investigated. The outer membrane of $S$. aureus has been inspected by examining the cells by SEM and determining protein leakage (Figs. 5A and $5 \mathrm{~B})$. S. aureus cells were treated with various concentrations $(0 \%, 25 \%, 50 \%, 75 \%$, and $100 \%(\mathrm{v} / \mathrm{v}))$ of AgNPs, then protein concentration was estimated in the supernatants (Fig. 5B). Notably, AgNPs have defected and possibly ruptured the outer membrane of $S$. aureus cells in comparison with untreated cells. To confirm whether AgNPs were able to increase the decomposition of genomic DNA, agarose gel electrophoresis was performed. Gel electrophoresis image (Fig. 5C) revealed that the bands of DNA of the treated cells have diminished and maybe fragmented as noticed with the plasmids DNA.

\section{Cytotoxicity Assay of AgNPs on Mammalian Cell Lines}

The cytotoxicity of AgNPs was assessed in vitro against two different cell lines; cervical cancer cell line (HeLa cells) and rat embryo fibroblast transformed cell line (REF cells) at different concentrations $(0 \%, 25 \%, 50 \%, 75 \%$, and $100 \%$ $(\mathrm{v} / \mathrm{v}))$. The data elucidate a direct dose-response relationship; cytotoxicity increased at higher concentrations (Fig. 6). A significant inhibition of HeLa cells was noticed; $25 \%$ (v/v) of AgNPs generates $~ 59 \%$ cell death in comparison with the REF cells since $25 \%(\mathrm{v} / \mathrm{v})$ resulted in $\sim 31 \%$ cell death.

\section{Discussion}

To our knowledge, this is the first study investigating the use of Fusarium mangiferae in synthesizing AgNPs. Ultimately, these findings support the hypothesis that F. mangiferae has

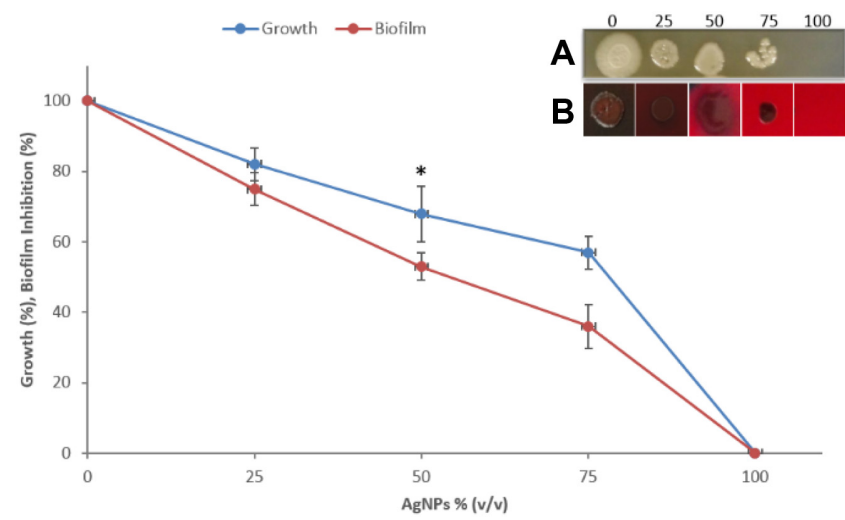

Fig. 4. Growth and biofilm inhibition of $S$. aureus in the presence of AgNPs using microtiter plate technique.

Bacterial cells adjusted to $1 \times 10^{8}$ per ml; $120 \mu \mathrm{l}$ broth culture were mixed with $80 \mu \mathrm{l}$ of different concentrations of AgNPs in each microtiter plate well. The plate was incubated for $18-24 \mathrm{~h}$ at $37^{\circ} \mathrm{C}$. Optical density was measured at $600 \mathrm{~nm}$ and $595 \mathrm{~nm}$ for growth and biofilm inhibition, respectively. Then readings were converted to growth (\%) and biofilm inhibition (\%). Inset: Five $\mu \mathrm{l}$ was taken from each well of growth inhibition assay plate and spotted onto the nutrient agar plate (A) and Cong red agar plates; pictures were taken from separate CRA plates (B). 


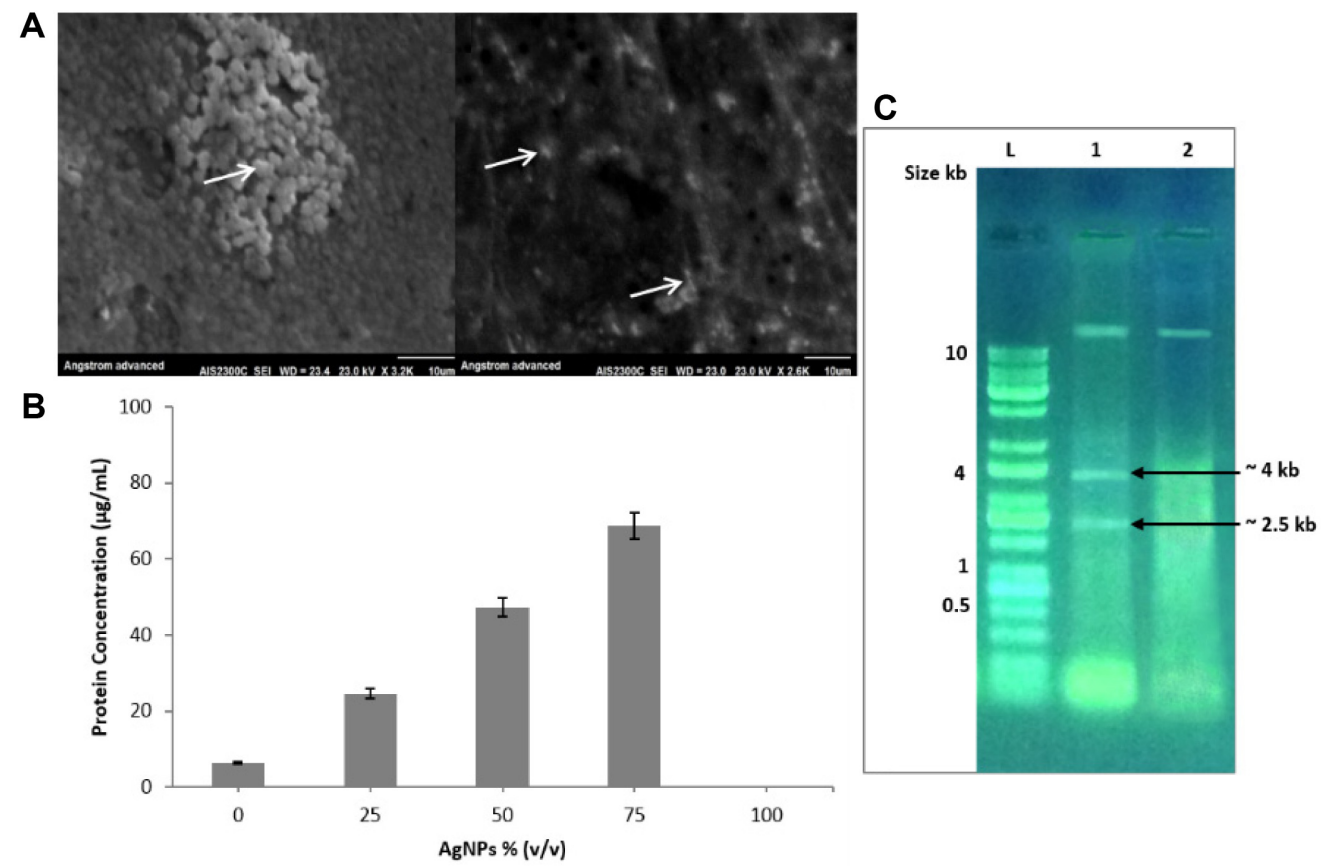

Fig. 5. Outer membrane disruption and DNA profile of S. aureus by the action of AgNPs.

(A) SEM images (Left picture depicts the untreated cells; whereas right picture represents the treated cells with 50\% AgNPs) (B) Protein leakage. (C) Genomic DNAs profile, black arrows represent plasmids profile. One percent agarose in TAE buffer was used and gel run at 80 Volts for an hour. Ladder used was $1 \mathrm{~kb}$.

the ability to drive AgNP formation, with equal or greater efficacy as compared to other Fusarium species. Furthermore, as a primary focus of this work, we observed successful antigrowth and antibiofilm activities of AgNPs by evaluating it against Staphylococcus aureus. Although this has not been

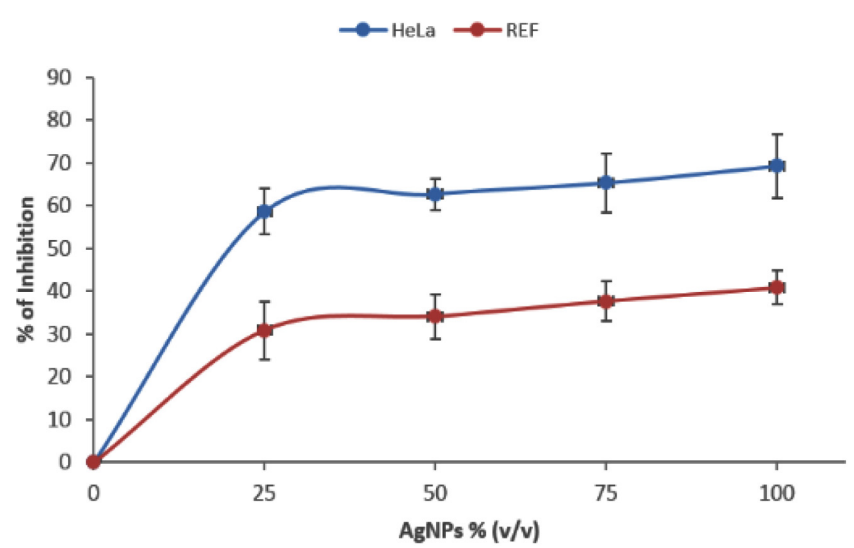

Fig. 6. Cytotoxic effect of AgNPs against HeLa and REF cell lines.

HeLa and REF cell lines were treated with different concentrations of AgNPs and incubated at $37^{\circ} \mathrm{C}$ for $24 \mathrm{~h}$. Cell death values were measured and converted to percentages of inhibition. designed to assess the mode of action against human cell lines, these results are promising and warrant further investigation. Therefore, future studies aimed at assessing the AgNPs' mode of action following HeLa cell line application, and producing ample and clinically feasible sources of AgNPs for testing in larger rodent and small animal studies are necessary to translate these findings to clinical use.

In this study, F. mangiferae showed resistance to relatively high concentrations of copper and silver metals (data not shown). FQ might develop a new survival strategy as an adaptive response to unfavorable environmental conditions, therefore this study offers some important insights into a plethora of unanswered questions concerning the mechanisms involved in metal resistance of fungal strains. FQ was able to reduce silver ions to silver NPs since it is well known that AgNPs in aqueous solutions show a yellowish brown color [1, 22]. The reduction took place through catalysis by the reducing agent secreted from the culture of FQ into the solution. Fusarium species have been used previously for NP production [1, 22, 37]; however, previous studies did not investigate $F$. mangiferae for the synthesis of AgNPs. The formation of AgNPs took about a week's incubation to develop the brown color. This slow 
silver reduction could be the result of undesirable growth surroundings, due to the presence of relatively high concentrations of silver nitrate. Mycosynthesis of silver NPs might occur by the activity of secreted reductase enzymes during the phases of fungal growth [37]. However, the limited fungal growth under such growth conditions may perhaps lead to the delayed excretion of the enzymes, which leads to the slow reduction of silver nitrate. Notably, the solution developed a dark brown color; therefore it was subjected and analyzed spectrophotometrically using UVVis in the scan range of 300-600 nm. Interestingly, AgNPs absorbed light at different wavelengths and were excited due to charge density at the interface between conductor and insulator to give a respective peak on UV-Vis spectrophotometry $[1,37]$. This finding is in agreement with several other studies [38, 39].

The SEM image of silver NPs shows aggregated particles, most likely due to the presence of the fungal metabolites that are acting as capping agents. Besides, high-density AgNPs with spherical shape were recognized by SEM. Similarly, a previous study has shown that the shapes of AgNPs synthesized by F. oxysporum were spherical to oval with little aggregation $[1,40]$. TEM and AFM are two of the most widely applied techniques to analyze the structure and size of NPs. Together these analyses provide considerable insight into the morphology and particle size distribution profile of the AgNPs synthesized by FQ. AFM threedimensional analysis showed the average roughness and inhomogeneity of the cluster formation of AgNPs. Various studies have reported that mycosynthesized AgNPs have spherical shapes and are uniformly distributed without significant agglomeration [1, 22, 41, 42]. Moreover, Gaikwad et al. [27] have compared the average size of AgNPs from six Fusarium species by TEM analysis, which confirmed the spherical shape of synthesized silver nanoparticles within the range of 2-68 nm. Further, Ingle et al. [23] showed that AgNPs from the fungus F. acuminatum were spherical with a broad size distribution in the range of 5-40 $\mathrm{nm}$.

Fungal extracellular metabolites, mainly proteins, are the putative biomolecules responsible for the capping and stabilizing of the nanoparticles detected by FTIR, which renders the formed AgNPs' potential for various real-life applications. In this study, the FTIR results corroborate the findings of previous work in this field [1]. The FTIR results also suggest that there is an association between the biopolymer protein and stability of AgNPs. The biopolymer forms a ligand-shell surrounding AgNPs at the core, forming a silver polymer core-shell structure. Consequently, the polymeric shell decreases the surface potential that is responsible for the accumulation of the silver nanoparticles to larger aggregates [41].

S. aureus is considered life-threatening due to its biofilm formation on surgical equipment, medical implants, and other devices, leading to diminished results of antibiotic treatment. Therefore, finding and perhaps fabricating a pervasive and environmentally friendly material to impede biofilm-forming bacteria is challenging. Antibacterial and antibiofilm activities of AgNPs have been appraised against multidrug-resistant gram-positive $S$. aureus. S. aureus shows resistance to a relatively high concentration of AgNPs, and this tolerance might be attributed to the presence of a selfproduced extracellular matrix in the isolate and its roles in the defense mechanisms $[43,44]$. Colonies of the slimeproducing strains manifest characteristic blackening on CRA. Accordingly, biofilm-forming clinical isolates of staphylococci show either black or dark-red colonies with accompanying dry crystalline consistency, whereas nonbiofilm producers might appear as dark colonies without crystalline formation [31, 45, 46]. The change in colony appearance might be attributed to side reaction between the slime production and Congo red, which ultimately yielded a distinctive coloration.

Although the inhibition of bacterial growth and biofilm development indicates that AgNPs possess a biocidal activity, the mechanisms that contribute to cell death is poorly understood. As anticipated, the cell membrane of S. aureus was deteriorated by the action of AgNPs, and it was clearly supported by the resulted protein content in the supernatant. The protein concentration was considerably high with the cells treated with AgNPs. It has previously been reported that AgNPs were able to adhere to the bacterial cell wall and produce cracks and pits, through which the internal cell contents are released [12]. Moreover, Prabhu and Poulose, 2012, have stated that AgNPs are involved in the disruption of the membrane with a generation of reactive oxygen species (ROS), which ultimately lead to the death of pathogens [10].

Gel electrophoresis was performed to evaluate the action of AgNPs on the genome of S. aureus. Noticeably, AgNPs reacted with DNA of $S$. aureus since both chromosomal and plasmids DNA seem to be reduced or degraded enormously in the case of treated cells. Additionally, the RNA smearing was immensely decreased. AgNPs possibly prevented DNA replication via binding, and eventually, causing cell death. Chen et al. [44] have reported that silver nanoparticles not only condense DNA, but also combine and coagulate with the cytoplasm of damaged bacteria, which results in the leakage of the cytoplasmic component. AgNPs could cause 
severe oxidative stress in $S$. aureus and might produce ROS leading to alteration of proteins, inhibition of enzymes, and nucleic acids reduction [9].

Based on the results obtained from the preliminary endeavor, and as noticed with the eukaryotic system, AgNPs exhibited cytotoxic effect against both HeLa and REF cell lines; however, HeLa cells were found to be more sensitive than REF cells. Based upon the results of the cytotoxicity assay, dose-response curves were extrapolated, and $\mathrm{IC}_{50}$ was found to be around $20 \% \mathrm{v} / \mathrm{v}$ for HeLa cell lines. HeLa cells and other human cancer-derived cell lines are commonly employed in medical studies for assessing the efficacy of chemotherapies, anticancer agents, drug quality control and testing the expression of recombinant proteins [47, 48]. Kaba and Egorova [49] have indicated the significant toxicity of AgNPs toward the HeLa and U937 tumor cells. Consequently, AgNPs may prove to be a possible candidate for the creation of corresponding antitumor drugs. AgNPs caused mitochondrial dysfunction as well as induction of ROS thereby causing changes in membrane structure and inducing DNA damage, chromosomal aberrations, and enzyme inactivation, which eventually leads to cell death [50]. Moreover, Salaheldin et al. [13] have reported that human breast carcinoma cell line MCF7 cells featured remarkable vacuolation, thus indicating a potent cytotoxic activity by the action of AgNPs synthesized by F. oxysporum. Sambale et al. [50] have found that silver nanoparticles induced apoptosis, whereas silver ions stimulated necrosis in four different mammalian cell lines.

Our work has led us to conclude that this study is likely to be of great interest to the vision of researchers who are interested in nanomedicine disciplines. This study has demonstrated, for the first time, that Fusarium mangiferae is harnessed to synthesize nanoparticles. The study here provides an exciting opportunity for the mode of action of AgNPs to advance the knowledge of using AgNPs as an alternative to antibiotics. This paper's findings also shed light on the toxicity of AgNPs on cervical cancer (HeLa) and non-cancerous rat embryo fibroblast transformed cell lines which were found to be dose-dependent. These findings offer a foundation for future animal studies to confirm our results and assess whether F. mangiferaeAgNPs can generate cell death at rates similar to anticancer medications with or without side effects.

\section{Acknowledgments}

The authors would like to thank Adiba Sharif at Sulaimani Technical Institute for her valuable help in doing some fungal experiments. The authors also thank the staff of the Central Service Laboratory at the University of Baghdad for assisting with AFM and FTIR analysis. We acknowledge the staff of the Kurdistan Institution for Strategic Studies and Scientific Research for their help during SEM analysis. We are grateful to the staff of the Chemistry Department at Al-Nahrin University for helping with TEM examination. Special thanks to Dr. Ahmed Al-Shamery at the Iraqi Center for Genetics and Cancer Research for his valuable help in doing the cytotoxicity assay. The authors would finally like to thank Dr. Ismaila Emahi of the University of Energy and Natural Resources, Ghana, for proofreading the manuscript.

\section{Conflict of Interest}

The authors have no financial conflicts of interest to declare.

\section{References}

1. Ahmed AA, Hamzah HM, Maaroof MN. 2018. Analyzing formation of silver nanoparticles from the filamentous fungus Fusarium oxysporum and their antimicrobial activity. Turk. J. Biol. 42: 54-62.

2. Miller JK, Neubig R, Clemons CB, Kreider KL, Wilber JP, Young GW, et al. 2013. Nanoparticle deposition onto biofilms. Ann. Biomed. Eng. 41: 53-67.

3. Radzig MA, Nadtochenko VA, Koksharova OA, Kiwi J, Lipasova VA, Khmel IA. 2013. Antibacterial effects of silver nanoparticles on gram-negative bacteria: influence on the growth and biofilms formation, mechanisms of action. Colloids Surf. B Biointerfaces 102: 300-306.

4. Costerton JW, Stewart PS, Greenberg EP. 1999. Bacterial biofilms: a common cause of persistent infections. Science 284: 1318-1322.

5. Syed MA, Babar S, Bhatti AS, Bokhari H. 2009. Antibacterial effects of silver nanoparticles on the bacterial strains isolated from catheterized urinary tract infection cases. J. Biomed. Nanotechnol. 5: 209-214.

6. Franci G, Falanga A, Galdiero S, Palomba L, Rai M, Morelli G, Galdiero M. 2015. Silver nanoparticles as potential antibacterial agents. Molecules 20: 8856-8874.

7. Archer NK, Mazaitis MJ, Costerton JW, Leid JG, Powers ME, Shirtliff ME. 2011. Staphylococcus aureus biofilms: properties, regulation, and roles in human disease. Virulence 2: 445-459.

8. Alt V, Bechert $T$, Steinrücke $P$, Wagener $M$, Seidel $P$, Dingeldein E, et al. 2004. An in vitro assessment of the antibacterial properties and cytotoxicity of nanoparticulate silver bone cement. Biomaterials 25: 4383-4391.

9. Beyth N, Houri-Haddad Y, Domb A, Khan W, Hazan R. 2015. Alternative antimicrobial approach: nano-antimicrobial 
materials. J. Evid. Based Complementary Altern. Med. 2015: 246012.

10. Prabhu S, Poulose EK. 2012. Silver nanoparticles: mechanism of antimicrobial action, synthesis, medical applications, and toxicity effects. Int. Nano. Lett. 2: 32.

11. Hwang IS, Hwang JH, Choi H, Kim KJ, Lee DG. 2012. Synergistic effects between silver nanoparticles and antibiotics and the mechanisms involved. J. Med. Microbiol. 61: 17191726.

12. Feng QL, Wu J, Chen GQ, Cui FZ, Kim TN, Kim JO. 2000. A mechanistic study of the antibacterial effect of silver ions on Escherichia coli and Staphylococcus aureus. J. Biomed. Mater. Res. 52: 662-668.

13. Salaheldin TA, Husseiny SM, Al-Enizi AM, Elzatahry A, Cowley AH. 2016. Evaluation of the cytotoxic behavior of fungal extracellular synthesized $\mathrm{Ag}$ nanoparticles using confocal laser scanning microscope. Int. J. Mol. Sci. 17: 329.

14. Sriram MI, Kanth SBM, Kalishwaralal K, Gurunathan S. 2010. Antitumor activity of silver nanoparticles in Dalton's lymphoma ascites tumor model. Int. J. Nanomedicine. 5: 753-762.

15. Arora S, Tyagi N, Bhardwaj A, Rusu L, Palanki R, Vig K, et al. 2015. Silver nanoparticles protect human keratinocytes against UVB radiation-induced DNA damage and apoptosis: potential for prevention of skin carcinogenesis. Nanomedicine 11: $1265-1275$.

16. Stensberg MC, Wei Q, McLamore ES, Porterfield DM, Wei A, Sepúlveda MS. 2011. Toxicological studies on silver nanoparticles: challenges and opportunities in assessment, monitoring and imaging. Nanomedicine 6: 879-898.

17. Hussain SM, Hess KL, Gearhart JM, Geiss KT, Schlager JJ. 2005. In vitro toxicity of nanoparticles in BRL 3A rat liver cells. Toxicol. In Vitro 19: 975-983.

18. Almofti MR, Ichikawa T, Yamashita $K$, Terada $H$, Shinohara $Y$. 2003. Silver ion induces a cyclosporine a-insensitive permeability transition in rat liver mitochondria and release of apoptogenic cytochrome C. J. Biochem. 134: 43-49.

19. Carlson C, Hussain SM, Schrand AM, Braydich-Stolle LK, Hess KL, Jones RL, et al. 2008. Unique cellular interaction of silver nanoparticles: size-dependent generation of reactive oxygen species. J. Phys. Chem. B 112: 13608-13619.

20. Soni N, Prakash S. 2012. Efficacy of fungus mediated silver and gold nanoparticles against Aedes aegypti larvae. Parasitol. Res. 110: 175-184.

21. Mishra A, Tripathy SK, Yun SI. 2011. Bio-synthesis of gold and silver nanoparticles from Candida guilliermondii and their antimicrobial effect against pathogenic bacteria. J. Nanosci. Nanotechnol. 11: 243-248.

22. Ahmad A, Mukherjee P, Senapati S, Mandal D, Khan MI, Kumar R, et al. 2003. Extracellular biosynthesis of silver nanoparticles using the fungus Fusarium oxysporum. Colloids Surf. B Biointerfaces 28: 313-318.

23. Ingle A, Gade A, Pierrat S, Sonnichsen C, Rai M. 2008. Mycosynthesis of silver nanoparticles using the fungus
Fusarium acuminatum and its activity against some human pathogenic bacteria. Curr. Nanosci. 4: 141-144.

24. Dasaratrao Sawle B, Salimath B, Deshpande R, Bedre MD, Prabhakar BK, Venkataraman A. 2008. Biosynthesis and stabilization of $\mathrm{Au}$ and $\mathrm{Au}-\mathrm{Ag}$ alloy nanoparticles by fungus, Fusarium semitectum. Sci. Technol. Adv. Mater. 9: 035012.

25. Ingle A, Rai M, Gade A, Bawaskar M. 2009. Fusarium solani: a novel biological agent for the extracellular synthesis of silver nanoparticles. J. Nanopart. Res. 11: 2079-2085.

26. Bawaskar M, Gaikwad S, Ingle A, Rathod D, Gade A, Durán $\mathrm{N}$, et al. 2010. A new report on mycosynthesis of silver nanoparticles by Fusarium culmorum. Curr. Nanosci. 6: 376-380.

27. Gaikwad SC, Birla SS, Ingle AP, Gade AK, Marcato PD, Rai M, et al. 2013. Screening of different Fusarium species to select potential species for the synthesis of silver nanoparticles. J. Braz. Chem. Soc. 24: 1974-1982.

28. Gamliel-Atinsky E, Sztejnberg A, Maymon M, Vintal H, Shtienberg D, Freeman S. 2009. Infection dynamics of Fusarium mangiferae, causal agent of mango malformation disease. Phytopathology 99: 775-781.

29. Omar NH, Mohd M, Nor NM, Zakaria L. 2018. Characterization and pathogenicity of Fusarium species associated with leaf spot of mango (Mangifera indica L.). Microb. Pathog. 114: 362-368.

30. Kaiser TD, Pereira EM, dos Santos KR, Maciel EL, Schuenck RP, Nunes AP. 2013. Modification of the Congo red agar method to detect biofilm production by Staphylococcus epidermidis. Diagn. Microbiol. Infect. Dis. 75: 235-239.

31. Mathur T, Singhal S, Khan S, Upadhyay DJ, Fatma T, Rattan A. 2006. Detection of biofilm formation among the clinical isolates of staphylococci: an evaluation of three different screening methods. Indian J. Med. Microbiol. 24: 25-29.

32. Kim SH, Lee HS, Ryu DS, Choi SJ, Lee DS. 2011. Antibacterial activity of silver-nanoparticles against Staphylococcus aureus and Escherichia coli. Korean J. Microbiol. Biotechnol. 39: 77-85.

33. Thottappilly G, Mignouna HD, Onasanya A, Abang M, Oyelakin O, Singh NK. 1999. Identification and differentiation of isolates of Colletotrichum gloeosporioides from yam by random amplified polymorphic DNA markers. Afr. Crop Sci. J. 7: 195-205.

34. Onasanya A, Mignouna HD, Thottappilly G. 2003. Genetic fingerprinting and phylogenetic diversity of Staphylococcus aureus isolates from Nigeria. Afr. J. Biotechnol. 2: 246-250.

35. Betancur-Galvis LA, Saez J, Granados H, Salazar A, Ossa JE. 1999. Antitumor and antiviral activity of Colombian medicinal plant extracts. Mem. Inst. Oswaldo Cruz. 94: 531-535.

36. Mather JP, Roberts PE. 1998. Introduction to Cell and Tissue Culture: Theory and Technique. pp 180-181. Plenum Press, New York.

37. Durán N, Marcato PD, Alves OL, De Souza GIH, Esposito E. 2005. Mechanistic aspects of biosynthesis of silver nanoparticles by several Fusarium oxysporum strains. J. Nanobiotech. 3: 8.

38. Gurunathan S, Jeong JK, Han JW, Zhang XF, Park JH, Kim JH. 
2015. Multidimensional effects of biologically synthesized silver nanoparticles in Helicobacter pylori, Helicobacter felis, and human lung (L132) and lung carcinoma A549 cells. Nanoscale Res. Lett. 10: 35.

39. Rodríguez-León E, Iñiguez-Palomares R, Navarro RE, Herrera-Urbina R, Tánori J, Iñiguez-Palomares C, et al. 2013. Synthesis of silver nanoparticles using reducing agents obtained from natural sources (Rumex hymenosepalus extracts). Nanoscale Res. Lett. 8: 318.

40. Kumar CM, Yugandhar P, Savithramma N. 2016. Biological synthesis of silver nanoparticles from Adansonia digitata L. fruit pulp extract, characterization, and its antimicrobial properties. J. Intercult. Ethnopharmacol. 5: 79-85.

41. Gopinath PM, Narchonai G, Dhanasekaran D, Ranjani A, Thajuddin N. 2015. Mycosynthesis, characterization and antibacterial properties of AgNPs against multidrug resistant (MDR) bacterial pathogens of female infertility cases. Asian J. Pharm. Sci. 10: 138-145.

42. Basavaraja SS, Balaji SD, Lagashetty AK, Rajasab AH, VenkataramanA. 2008. Extracellular biosynthesis of silver nanoparticles using the fungus Fusarium semitectum. Mater. Res. Bull. 43: 1164-1170.

43. Majeed S, bin Abdullah MS, Nanda A, Ansari MT. 2016. In vitro study of the antibacterial and anticancer activities of silver nanoparticles synthesized from Penicillium brevicompactum (MTCC-1999). J. Taibah Univ. Sci. 10: 614-620.
44. Chen M, Yang Z, Wu H, Pan X, Xie X, Wu C. 2011 Antimicrobial activity and the mechanism of silver nanoparticle thermosensitive gel. Int. J. Nanomedicine. 6: 2873-2877.

45. Kiem S, Oh WS, Peck KR, Lee NY, Lee JY, Song JH, et al. 2004. Phase variation of biofilm formation in Staphylococcus aureus by IS256 insertion and its impact on the capacity adhering to polyurethane surface. J. Korean Med. Sci. 19: 779782.

46. Milanov D, Lazić S, Vidić B, Petrović J, Bugarski D, Šeguljev Z. 2010. Slime production and biofilm forming ability by Staphylococcus aureus bovine mastitis isolates. Acta Vet. Brno. 60: 217-226.

47. Abdeen SH, Abdeen AM, EI-Enshasy HA, Shereef AAE. 2011. HeLa-S3 cell growth conditions in serum-free medium and adaptability for proliferation in suspension culture. $J$. Biol. Sci. 11: 124-134.

48. Gillet JP, Varma S, Gottesman MM. 2013. The clinical relevance of cancer cell lines. J. J. Natl. Cancer Inst. 105: 452-458.

49. Kaba SI, Egorova EM. 2015. In vitro studies of the toxic effects of silver nanoparticles on HeLa and U937 cells. Nanotechnol. Sci Appl. 8: 19-29.

50. Sambale F, Wagner S, Stahl F, Khaydarov RR, Scheper T, Bahnemann D. 2015. Investigations of the toxic effect of silver nanoparticles on mammalian cell lines. J. Nanomater. 16: 6 . 